\title{
Autorsky rozeklaný portrét dvojčat
}

\author{
Luboš Mareček
}

Věra Staňková. Sestry Machatovy. Neobyčejný přiběh slavných dvojčat. Grada Publishing, a.s., 2019. 272 s. ISBN 978-80-271-2273-8

Neobvyklou kariéru slavných brněnských dvojčat opisuje knížka Sestry Machatovy, kterou předloni vydalo Grada Publishing. Ona natuknutá nevšednost profesního snažení obou dam tkví ve skutečně nezvyklém propojení světa vrcholového sportu a špičkového umění. Jmenovaná sourozenecká dvojice známá jako Machatky (roč. 1938) má totiž za sebou mezinárodně úspěšnou kariéru moderních gymnastek, k níž obě téměř paralelně - budovaly svoji sólistickou dráhu v brněnském baletu. Autorka knihy Věra Staňková v jisté neproporčnosti věnuje toliko pětinu knihy baletnímu působení obou sester. Drtivá většina knihy mapuje jejich barvitý sportovní život; čtenář se však na počátku i závěru svazku o cca 270 stranách dočká také autorčina pohledu do osobního rodinného života portrétovaných.

Podtitul knihy Neobyčejný příběh slavných dvojčat dvěma použitými adjektivy šroubovanými do superlativů láká na cosi výjimečného sice marketingově správně, tento ponejvíce popularizační spisek toho však vážným zájemcům o taneční umění příliš nenabídne. Výsledný knižní tvar jistě zaujme většinového čtenáře nebo někdejší fanoušky mimořádného sesterského dua či příznivce sportovní historie. Nejen kvůli naznačenému nepoměru ale o jeho větší teatrologické hodnotě nemůže být řeč, na publikovaný výsledek nejde příliš napasovat ani signum odborné literatury. Pojd'me vyložit a domýšlet, proč tomu tak je.
Paradoxně mnohé napoví už vhled do webových stránek Grada Publishing, což je podle jejich vlastních proklamací největší nakladatelství odborné literatury působící v České republice, a ještě před deseti lety druhé největší mezi českými nakladateli vůbec. Tento nakladatelský dům působící v tuzemsku od roku 1991 nabízí opravdu široké spektrum knih z nejrůznějších oblastí lidské činnosti od zdravotnických a lékařských publikací, přes stavebnictví, architekturu, pedagogiku, psychologii, právo, daně a účetnictví až po kuchařky a antistresové omalovánky. Titul Sestry $M a$ chatory $\mathrm{v}$ této kvantitativně i kvalitativně velmi široké nabídce objevíte v sekci Beletrie věnované memoárům, osobnostem a osudům. Důležitější je ovšem sám fakt, že recenzovaný spisek $\mathrm{v}$ této masivní vydavatelské produkci přiléhá ke světu divadla jako jediný, a i to se zřejmě na jeho odborné jakosti projevilo. V úžeji, uměnovědně či přímo teatrologicky specializovaném vydavatelském domu by zřejmě vyjít nemohl, protože postrádá nejen vnější znaky odborné publikace, at’ už mluvíme o architektuře knihy, absenci jmenného či věcného rejstříku a poznámek pod čarou, normovaných bibliografických zápisů, ale zejména odbornějšího vhledu na umělecký život sester, hodnocení nebo analýzy jejich výkonů. Ve zdánlivém protikladu k výše řečenému, širokospektrální záběr Grada Publishing, do kterého se dá skrýt 
jakákoliv produkce, není na závadu. Je totiž úplně jedno, zda má výsledná kniha být vědeckou monografií, literárním životopisem, biografickou beletrií nebo čímkoli jiným. Bez ohledu na žánr má v podobných publikacích jít ale vždy o směs faktů, které je nezbytné doplňovat jejich permanentní interpretací; její absence, myslím, představuje ústřední nedostatek knihy Sestry $M a$ chatovy. Chybí tak nejen žádoucí hodnocení tématu, ale i ráznější autorský podhled na vybranou látku, který by právě ze zasvěcených komentářủ a výkladu jasně vzlínal, demonstroval autorčiny postoje a také důvody, proč právě tento materiál a v této podobě čtenáři předkládá.

Výsledný produkt ponejvíce myslel na většinového čtenáře (z textu je znát, že autorka nemá žádné teatrologické školení, odbornější slovník by zájemce, tedy pamětník či fanoušek sester z nevyhraněné, majoritní čtenářské obce, ani neskousnul), což samozřejmě autorce nelze mít nijak za zlé. Z ročníku narození obou výjimečných sester lze navíc lehce odvodit, že kniha vydávaná rok po osmdesátých narozeninách protagonistek představuje také zaslouženou hommage tohoto významného kulatého výročí obou jubilantek i jejich jedinečné kariéry.

I tak myslím autorka mohla překročit jistou spotřební a lehce konzumovatelnou povahu svého díla, které je zejména (sice zaslouženým) oslavným pajánem méně však již seriózním vědeckým pohledem, komentářem a interpretací těchto výkonů v dobovém kontextu. Staňková předkládá ponejvíce rutinní popis, používá prosté chronologické deskripce a do jisté míry jen mechanicky kupí faktografické údaje o obou ženách. Dělá to suše jako se prezentují výsledky ve sportu, a to i přes nezastíranou a místy programově demon- strovanou spřízněnost pisatelky s portrétovanými. I přes beletrizující povahu výsledku tady však nejde o krásnou literaturu, v těžišti autorského zájmu by mělo být věcné, ale vědečtější uchopení.

Trio se scházelo po tři měsíce na jaře roku 2017 a posléze ještě nepravidelně po celý rok. Nemusíme soudit, zda je to moc nebo málo na zasvěcený výzkum, důležitý je výsledek. Autorce podle vlastních slov šlo o to, „složit společný příběh dvou prolínajících se životů, které se dodnes podobají jako slavná dvojčata a současně se odlišují jako jejich charaktery i soukromé osudy“ (12). Nutno konstatovat, že Staňková $\mathrm{s}$ oběma sestrami poctivě jejich životy prošla a zaznamenala nejpodstatnější sportovní trofeje i pracnou a strastiplnou cestu k nim. Diskutabilnější je ale sám fakt, jakou formou je představuje čtenáři. Vlastní deskripci v některých kapitolách střídá autentický přepis dětských deníkový zápisů (33), některé z kapitol jsou nadepsány inscenovanými dialogy $(43,47,191 \ldots)$, oranžovou kurzívou jsou ve vlastním textu vyznačeny citace $\mathrm{z}$ dobového tisku, jindy jednu kapitolu tvoří jednostránková citace vzpomínky sportovního komentátora Jaroslava Suchánka (154) nebo jsou zde „kapitoly“ tvořené prostým výčtem sportovních medailí, umístění a ocenění nebo (slovníkem autorky) „přehled divadelních rolí“, v nichž zoufale chybí jméno režiséra a choreografa konkrétní inscenace. Tato načechraná textová i formální skrumáž je hustě prokládána fotografiemi a orientovaná i takto na výše predikovaného čtenáře. Ostatně Staňková už svou předchozí autobiografii věnovanou významné brněnské herečce Zdeně Herfortové spisovatelsky inscenovala $\mathrm{v}$ ich formě - tento zvolený př́stup měl budit uživatelský dojem autenticity; tehdy i nyní se ukazují limity 
podobného portrétování umělců bez většího odborného aparátu. Svérázné zacházení s prameny je tady několikrát i na pováženou. Př́ḱladem je autorské vymýšlení si citovaných přímých řečí a jejich - pro větší sugestivitu - vkládání do úst kupř́íkladu redaktoru bělehradského časopisu Sport (78) nebo ještě dříve v kapitole nadepsané Machatky pohledem Jiřiny Šlezingerové. Tato významná primabalerína (roč. 1925) a sólistka baletu Státního divadla v Brně (nositelka Ceny Thálie 2007 za celoživotní mistrovství) obě sestry tři roky vedla na konzervatoři a vzpomíná na ně jako na své nejlepší žačky (63). Namnoze banální historky ze studentského života by jistě vhodněji suplovala možná rekonstrukce dobové taneční pedagogiky nebo i pozdějších sólistických výkonů očima a slovníkem této jedinečné profesionálky. „Baby jedny, všechno uměly!“ lakonickými slovy vzpomíná (65) tanečník Karel Fux (taktéž roč. 1938) a jejich častý divadelní partner, který vloni zesnul. Pružný a dynamický sólista baletu NDB s výraznou mimikou, představitel především charakterních a komických rolí šel jistě vytěžit více než toliko reflexí, že dvojčatům záviděl jejich popularitu.

Přitom velká jména baletního umění kariéru sester Machatových provázela od počátku. Prvním divadelním choreografem dvojčat byl Jiří Nermut, který je do brněnského Národního divadla vybral už v prvním ročníku konzervatoře do rolí pážat v baletu Romeo a Julie. V roce 1957 obě sportovkyně vstoupily do stálého angažmá v baletním souboru Státního divadla v Brně; účinkovaly jako sboristky nejen v mateřském souboru, ale také $\mathrm{v}$ produkcích činoherních a operních. Posléze došlo k vydělení dvou skupin tzv. velkého baletu a baletu operního. Sestry Machatovy skončily ve velkém tělese, které neprodukovalo toliko komparz k výpravnému opernímu žánru, ale vytvářelo vlastní celovečerní produkce. Ve vršení zábavných historek se naštěstí tu a tam objeví praktická relevantní informace, že „dostaly v roce 1968 smlouvy jako sólistky s povinností tančit ve sboru. Denně od 9 do 13 hodin zkoušely. Běžně tančily 18 představení za měsíc, v repertoáru měly šest baletů, čtyři opery a zájezdová představení“ (165).

Je ale velká škoda, že se autorka nepokusila o hlubší zprostředkování atmosféry tehdejšího baletu či se přes vzpomínky portrétovaných a dobové prameny nepokusila o rekonstrukci některé z významných inscenací či o precizování metod a uměleckého přístupu některého ze šéfů a choreografů opravdu zvučných jmen: Miroslav Kůra, Luboš Ogoun, Pavel Šmok, Jiří Němeček nebo Rudolf Karhánek. V jádru jde vlastně jen o výčet rolí bez většího komentáře či o triviální vzpomínky typu, že se s kolegyněmi ze čtyřmístné dámské šatny téměř nikdy po premiéře nechodilo na skleničku. Knihu možná oživují ale její výpovědní hodnotu stejně tak banalizují poznámky o uklouznutí na šlehačce nebo úklidu začerněných sprch po výkonu v roli černošky s nadměrným používání tmavé tělky či o přesvědčivém jevištním skonu po bodnutí do zad v jiné úloze nebo o šlápnutí na hřebík při jedné produkci. Tyto veselé i smutné historky $\mathrm{k}$ umělecké dráze patří, jejich inflační použivání poněkud snižuje hloubku výpovědi a vlastně i kvalitu těchto tanečních výkonů, které tady nejsou seriózně hodnoceny ze žádné optiky: at̉ už stran odborníků či kolegyň a pomyslných konkurentek. Přitom žádná z obou tanečnic neměla stálého tanečního partnera, což byla doména výhradně hlavních sólistek a primabalerín. Celá kapitola Šedesátá až osmdesátá léta shrnující 
na čtyřech půlstranách (!) baletní snažení cí v Janáčkově divadle. To jsou ale toliko sester je uzavřena sdělením, že se jim pro vnější znaky a účelově využívaná spřízněschopnost okamžitě někoho v menší roli nost. Důležitější je samozřejmě sportovní zastoupit ř́ikalo záskokářky.

a umělecká výkonnost, která byla u této

Sestry Machatovy skutečně zosobňují je- dvojice v rovnováze a žádnou ze sester dinečný fenomén, který tkví v koexistenci jako by neupozad’ovala. Snaha o neproblea vzájemném prorůstání světa vrcholového matickou i neproblematizovanou čtivost sportu a tanečního umění. Jistým (na spor- ale výsledek poněkud degraduje. Přesto je tovištích i jevištích) využívaným kouzlem důležité, že podobné memorabilie vznikav tomto případě byla nerozeznatelná po- jí. Třeba se stanou odrazovou platformou doba těchto jednovaječných blíženců, kte- pro serióznější práci s prameny i materirou autorka samožrejmě konstatuje. Ostat- álem v budoucí, kvalitněji rozvržené i seně dvojici fyzicky identických děvčat takto psané monografii, kterou si sesterské duo posléze využívali režiséři baletních inscena- nepochybně zaslouží. 